\title{
Nuclear Receptor-Interacting Protein 1
}

National Cancer Institute

\section{Source}

National Cancer Institute. Nuclear Receptor-Interacting Protein 1. NCI Thesaurus. Code C17929.

Nuclear receptor-interacting protein 1 (1158 aa, $\sim 127 \mathrm{kDa}$ ) is encoded by the human NRIP1 gene. This protein plays a role in the modulation of steroid and hormonedependent gene expression. 